\title{
Prevention of cancer cervix: developing a task force
}

\author{
A. Parimala, Nidhi Sharma*, Jayashree K. Srinivasan
}

Department of Obstetrics and Gynaecology, Saveetha Medical College, Saveetha University, Chennai, India

Received: 30 June 2016

Revised: 07 July 2016

Accepted: 11 July 2016

\section{*Correspondence:}

Dr. Nidhi Sharma,

E-mail: drbonuramkumar@yahoo.co.in

Copyright: (C) the author(s), publisher and licensee Medip Academy. This is an open-access article distributed under the terms of the Creative Commons Attribution Non-Commercial License, which permits unrestricted non-commercial use, distribution, and reproduction in any medium, provided the original work is properly cited.

\begin{abstract}
Background: Cancer cervix is the most common cancer in women of the developing countries where screening facilities are inadequate. Cancer cervix is a preventable cancer due to its long pre invasive stage and availability of screening methods. Colposcopy is an in situ clinical examination of cervix with magnification and illumination. It is a clinical method that complements the laboratory method of cytology in identifying the site of origin of dysplastic cells. Developing a task force for prevention of cancer cervix requires training of medical and paramedical staff.

Methods: The study was conducted as a one-day live demonstration workshop on screening of cancer cervix in the department of obstetrics and gynecology in Saveetha Medical College, Chennai. Colposcopy Reid's index calculation was demonstrated on twelve women. Sixty-four medical and paramedical health workers identified the pre-invasive lesion under magnification and green filter application. Acetic acid and Lugol's iodine staining was done. Pretest and posttest helped the teaching faculty to assess the level of competency achieved.

Results: The colposcopy-training workshop equipped the health workers to detect and treat the preinvasive cancers. Primary prevention by elimination of risk factors and HPV vaccination is difficult and expensive but secondary prevention by means of mass screening and treatment of precancerous lesion can reduce the progression to cancer cervix. The strategy, however is not to lower the incidence of cancer cervix, but to minimize cancer death due to early detection.

Conclusions: A women with a preinvasive lesion of cancer cervix can be asymptomatic. This requires a task force for mass screening of all women in the community. Community health workers begin screening of all women from 21 years onwards with Pap smear and colposcopy. The trained heath workers can be used for downstaging of cancer cervix leading to a dramatic reduction in the incidence of invasive carcinoma. Even when a colposcopist detects the invasive carcinoma, it is so early that an $85-100 \%$ five-year survival rate can be achieved.
\end{abstract}

Keywords: Colposcopy, Cancer cervix, Down staging, Secondary prevention

\section{INTRODUCTION}

In 1925, Hinselmann H. et al first described the benefit of using a binocular dissecting microscope and an intense light source to clinically examine cervix and vagina. ${ }^{1}$ The history of colposcopy has a legacy. Eduard wirths, the chief SS Doctor at Auschwitz, was a former student of Hinselmann. ${ }^{2}$ Eduard Wirths surgically removed the cervices from thousands of female concentration camp inmates and studied the tissues. ${ }^{2}$ Hinselmann introduced the application of acetic acid and in 1936 further described punctuations, ground leukoplakia, and mosaic patterns. Concurrently, Schiller W. developed the Iodine test. $^{3}$ At the end of second world war, Hinselmann was imprisoned for war crimes including the acts mentioned above. ${ }^{2}$ Presently, colposcopy is integrated in the medical curriculum of the University to diagnose the site of biopsy after abnormal cytology. Cervical cancer is the fourth most common cancer among all organs, leading cause being the breast and is the most common 
gynecological cancer in the world. Majority of Indian women have never been screened for the disease and $70 \%$ of these cases present as advanced cancer due to absence of any screening. ${ }^{4}$ It is estimated that there will be around 205,496 new cases and 119,097 deaths due to cervical cancer by 2020 in India. 5 These predictions might understate the burden of cancer cervix. Cancer registries and surveillance system in India provide inadequate information as they not complete and comprehensive. Cancer incidence data published by the main agencies, national cancer registry programme (NCRP) of India, the cancer atlas of India, the Cervix Uteri (ICD 10:C53), and the GLOBOCAN has unequal representation of different parts of India, that is, under representation of east, far north, and rural India and the data is only from major cities, hospitals and medical colleges. ${ }^{6}$

\section{METHODS}

The patient is placed in a lithotomy position on a motorized gynecologic examination table. With the colposcope in position, the examination table is adjusted to a height (that is comfortable for examiner). A console contains the cervical speculum, a broom cytology brush, wooden spatula, cotton tip applicators, a fixative bottle, $5 \%$ acetic acid, Lugols Iodine and a biopsy forceps. The magnification is set on scanning power (x4). Experts in four steps inspected the cervix.

Step 1: The external genitalia, the perianal skin and vestibule is examined. A Cusco's speculum is inserted and opened carefully to expose the cervix midway between the anterior and posterior blades of speculum. Visualization of transformation zone, ectocervix and vaginal fornices is done. A pap smear is performed first with a spatula and then with cytobrush. ${ }^{5}$ To visualize the endocervical canal a gentle manipulation with cotton tip applicator and magnification (x6) is helpful. A large cotton tip applicator was used to swab away vaginal discharges. This included visualization of islands of columnar epithelium surrounded by metaplastic squamous epithelium. Cervicovaginal junction was also visualized. The posterior wall of vagina was flattened and placed on traction by rotating the speculum 90 degrees.

Step 2: Acetic acid (5\%) was applied two or three times with cotton tips applicator or spayed gently to coagulate the cell protein cytokeratin. The examiner douches the cervix lightly, taking care to avoid rubbing the tissue. After 30-40 seconds, the magnification is increased (x10) and transformation zone is studied from 12 O'clock position in a clockwise manner. Acetowhite epithelium was seen in immature squamous metaplasia, viral infections, CIN 1, 2 and 3. After acetic acid application, the color of endocervical mucosa changed from red orange to pink and the mucosa appears grape like i.e. the papillae coalesce. If any abnormalities were found they were graded after increasing the magnification (x16 to $\mathrm{x} 25)$.
Step 3: Study after Lugol's iodine (potassium iodide with $5 \%$ elemental iodine). Positive iodine uptake areas produced a mahogany brown color and negative uptake presented a high-grade lesion (CIN 3).

Step 4: Performance of endocervical sampling or cervical biopsy. The magnification was decreased $(x 4)$ to view a larger field while taking biopsy. Monsel's solution finally, the speculum was rotated to expose the lower vagina and introitus. The lateral wall of vagina was seen when the colposcope was angled to aim the light between blades of the speculum. Green filter was used only to sharpen the contrast to view vascular changes. As it filters the red wavelength and vessels appear black it should be used only for the relevant part of the examination. Office contact hysteroscopy and guided biopsy may be performed in the endocervical canal if any suspicion of glandular abnormalities is detected in papsmear Reid's colposcopy index was calculated for all cases and clinically correlated (Table 1). ${ }^{8,9} \mathrm{By}$

- Assessing margins (score $0=$ regular, well defined, score $1=$ irregular well defined, score $2=$ irregular ill defined).

- Color (score $0=$ no acetowhite areas, score $1=$ few cloudy acetowhite areas, score $2=$ white opaque acetowhite areas)

- Vascular pattern (score $0=$ normal vessels, score $1=$ abnormal vessels, score $2=$ mosaic patterns)

- $\quad$ Iodine Uptake (score $0=$ mahogany brown, score $2=$ no iodine uptake areas)

- Pretest and posttest was conducted using colpophotographs and Odell's diagram.

The scores obtained were plotted using box charts for pretest and posttest. The median, the $25^{\text {th }}$ percentile, the 75th percentile and the maximum and minimum score values in pretest and posttest were plotted using sigma plot (Figure 1).

Table 1: Reid's colposcopy index.

\begin{tabular}{|lll|}
\hline Reid's index & Score & Impression \\
\hline I & $0-2$ & HPV \\
\hline II & $3-5$ & CIN 1 or CIN 2 \\
\hline III & $6-8$ & CIN 2 or CIN 3 \\
\hline
\end{tabular}

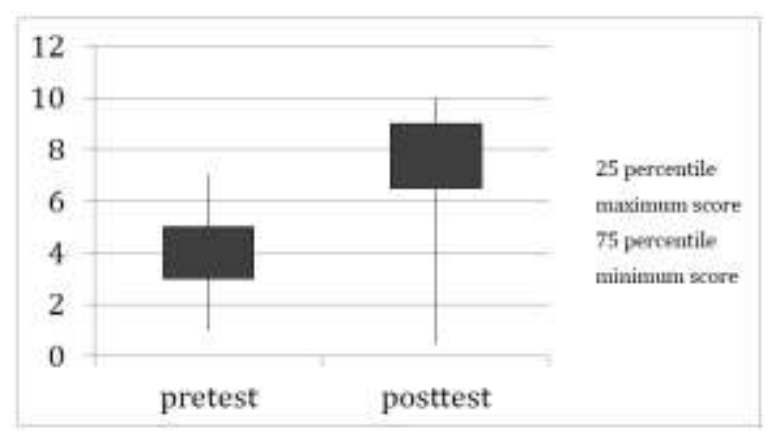

Figure 1: Pretest and posttest analysis. 


\section{RESULTS}

The international federation of cervical pathology and colposcopy (IFCPC) 2011, colposcopic terminology was used to note the observations (Table 2,3). ${ }^{10}$

Transformation zone squamocolumnar junction is indrawn in postmenopausal women and requires an endocervical speculum or a fine cervical hook for visualization. The cells associated with invasive carcinoma are more bizarre and pleomorphic than those seen in preinvasive disease. A well-developed severe mosaic pattern usually suggests CIN 2 or 3 .

Table 2: Cervical colposcopy terminology (IFCPC 2011).

\begin{tabular}{|c|c|}
\hline \multicolumn{2}{|r|}{ Cervix colposcopy } \\
\hline $\begin{array}{l}\text { General } \\
\text { assessment }\end{array}$ & $\begin{array}{l}\text { Adequate or inadequate for the } \\
\text { reason(e.g cervix being obscured by } \\
\text { inflammation, bleeding, scar) } \\
\text { Squamocolumnar junction visibility : } \\
\text { completely visible, partially visible, not } \\
\text { visible, Transformation type } 1,2,3\end{array}$ \\
\hline $\begin{array}{l}\text { Normal } \\
\text { colposcopy } \\
\text { findings }\end{array}$ & $\begin{array}{l}\text { Original squamous epithelium : mature, } \\
\text { atrophic, columnar epithelium : } \\
\text { ectopic/ectropion, Metaplastic } \\
\text { squamous epithelium, nebothian cysts, } \\
\text { crypts (gland openings ), deciduosis in } \\
\text { pregnancy }\end{array}$ \\
\hline $\begin{array}{l}\text { Abnormal } \\
\text { colposcopy } \\
\text { findings }\end{array}$ & $\begin{array}{l}\text { Location of the lesion-inside or outside } \\
\text { the transformation zone, location of } \\
\text { lesion by clock position, size of lesion, } \\
\text { number of cervical quadrants the lesion } \\
\text { covers, size of lesion as percentage of } \\
\text { cervix, grade } 1 \text { (minor): fine mosaic, } \\
\text { fine punctuation, thin acetowhite } \\
\text { epithelium, irregular geographic border, } \\
\text { grade } 2 \text { (major) : sharp border, inner } \\
\text { border sign, ridge sign, dense } \\
\text { acetowhite epithelium, coarse mosaic, } \\
\text { coarse punctuation, rapid appearance of } \\
\text { acetowhitening, cuffed crypt (gland } \\
\text { openings). Non specific-leukoplakia } \\
\text { (keratosis, hyper keratosis), erosion. } \\
\text { Lugol's staining-stained or non-stained }\end{array}$ \\
\hline $\begin{array}{l}\text { Suspicious for } \\
\text { invasion }\end{array}$ & $\begin{array}{l}\text { Atypical vessels, fragile vessels, } \\
\text { irregular surface, exophytic lesion }\end{array}$ \\
\hline $\begin{array}{l}\text { Miscellaneous } \\
\text { findings }\end{array}$ & $\begin{array}{l}\text { Congenital transformation zone, } \\
\text { condyloma, polyp (ectocervical or } \\
\text { endocervical), inflammation, stenosis, } \\
\text { congenital anomaly, post treatment } \\
\text { consequence, endometriosis }\end{array}$ \\
\hline
\end{tabular}

\section{Acetic acid application}

After acetic acid application a diffuse mosaic pattern without white epithelium or ground leukoplakia usually suggests physiological squamous metaplasia. Cloudy white epithelium after acetic acid, also suggest squamous metaplasia. Plaques or streaks of pebbly white epithelium, after acetic acid suggests condylomatous patches. A widely spaced well developed mosaic pattern seen against white epithelium or ground leukoplakia suggest CIN 3.

\section{Table 3: Vaginal colposcopy terminology (IFCPC 2011).}

\begin{tabular}{|ll|}
\hline $\begin{array}{l}\text { General } \\
\text { assessment }\end{array}$ & $\begin{array}{l}\text { Adequate or inadequate for reason } \\
\text { (bleeding, inflammation, scar), } \\
\text { Transformation zone }\end{array}$ \\
\hline $\begin{array}{l}\text { Normal } \\
\text { colposcopy } \\
\text { findings }\end{array}$ & $\begin{array}{l}\text { Squamous epithelium-mature or } \\
\text { atrophic }\end{array}$ \\
\hline & Upper third or lower two third, \\
& $\begin{array}{l}\text { Anterior, posterior, lateral (right/left), } \\
\text { Grade 1 (minor)-thin acetowhite } \\
\text { epithelium, fine punctuation, fine } \\
\text { mosaic, grade 2 (major)-dense }\end{array}$ \\
Abnormal \\
colposcopy \\
findings & $\begin{array}{l}\text { punctuation, coarse mosaic, } \\
\text { Suspicious for invasion-atypical } \\
\text { vessels, additional signs-fragile } \\
\text { vessels, irregular surface, exophytic } \\
\text { lesion, necrosis, ulceration, tumour, } \\
\text { Columnar epithelium (adenosis), }\end{array}$ \\
& $\begin{array}{l}\text { Lugol's staining-staining or not } \\
\text { stained, leukoplakia }\end{array}$ \\
\hline $\begin{array}{l}\text { Eiscellaneous } \\
\text { Eindings }\end{array}$ & $\begin{array}{l}\text { cysts, endometriosis, inflammation, } \\
\text { vaginal stenosis, congenital } \\
\text { transformation zone }\end{array}$ \\
\hline
\end{tabular}

\section{Vessel patterns}

Fine punctuations; suggest inflammation but wide punctuations in a background of white epithelium suggest CIN 2 or 3. Intermediate inter capillary distance suggest CIN 1.

\section{Iodine staining}

Iodine uptake areas are stained mahogany brown due to glycogen, whereas negative uptake areas are high grade CIN 3.

\section{DISCUSSION}

A thorough knowledge of basic colposcopy normal findings is essential for physicians and policy makers. Participatory learning activities keep students alert and interested. Primary prevention by elimination of risk factors and HPV vaccination is difficult and expensive but secondary prevention by means of mass screening and treatment of precancerous lesion can reduce the progression to cancer cervix. ${ }^{11,12}$ Colposcopy live demonstration workshop was conducted to teach basics to 
beginners, and refined principals to those with experience and to update the practicing colposcopists. The secondary outcome will be achieved when trainees will be able to diagnose the premalignant lesions of cancer cervix and document cure. ${ }^{13}$

\section{CONCLUSION}

The health workers were able to comprehend colposcopy from its basics. The colposcopy examination was called adequate only when squamocolumnar junction was completely visualized. The health worker realized that CIN 1 lesions were common could be observed in young women and require only follow up. CIN 2 and 3 lesions should be treated, either by ablative or excisional methods. Ablative methods should be used only if colposcopy is satisfactory and there are no glandular or endocervical lesions. The case based colposcopy demonstration improved their skills.

Funding: No funding sources

Conflict of interest: None declared

Ethical approval: The study was approved by the Institutional Ethics Committee

\section{REFERENCES}

1. Hinselmann H. Verbesserungen der Inspektionsmöglichkeiten von vulva, vagina und Portio. Münch Med Wochenschr 1925;72:1733.

2. Michael SB. Colposcopy of the cervix, vagina and vulva. A comprehensive textbook. Elsevier Health Sciences. MOSBY; $1^{\text {st }}$ edition,Philadelphia PA.USA;2003. Available at www.jmig.org/article/S1074-3804(05)602186/abstract. Accessed on 15 June 2016.

3. Schiller W. Uber fruhstadien des Portiocarcinoms und ihre diagnose. Arch Gynakol. 1928;133:211-83.

4. Parham GP, Andrews NR, Lee ML. Comparison of immediate and deferred colposcopy in a cervical screening programme. Obstet Gynecol. 2000;95:3404.

5. Ferlay J, Bray F, Pisani P, Parkin DM. Globocan, 2002 cancer incidence, mortality and prevalence worldwide. Lyon, France: IARC press; 2004 (Version 1.0. IARC Cancer Base No. 5).

6. Pollock AM, Brhlikova P, Mattheij I. Author's Response: HPV vaccination in India. J Royal Soc Med. 2012;105(9):366.

7. Papanicolau GN, Traut HF. Diagnosis of uterine cancer by the vaginal smear. New York, Commonwealth Fund, 1943. Available at www.actacytol.com/historicalperspective/CenturyforCytopatho logy. Accessed on 15 June 2016.

8. Reid R, Scalzi P. Genital warts and cervical cancer: an improved colposcopic index for differentiating benign papilloma viral infections from high-grade cervical intraepithelial neoplasia. Am J Obstet Gynaecol. 1985;153:611-8.

9. Ferris DG, Litaker MS. ALTS group prediction of cervical histological results using an abbreviated reid's colposcopic index during ALTS. Am J Obstet Gynaecol. 2006;194:704-10.

10. Update on colposcopic terminology-WHEC Practicebulletin and clinical management guidelines for health care providers. Available at www.womenshealth section.com / content / gynpc / gynpc008 .php3. Accessed on 20 March 2016.

11. Vasey PA. New approaches to cervical cancer screening: developing an effective programme for the world. Presented at the 10th European cancer conference, September 15, 1999. Available online at www.medscape.com/medscape/cno/1999.ECCO/Stor y.cfm?story_id=783. Accessed on 20 March 2016.

12. Krishnegowda S, MS V. Efficacy of colposcopy technique with pap smear and histology in screening of cervical lesions. Int J Reprod Contracept Obstet Gynecol. 2014;3(3):696-702.

13. Benedet JL, Matisic JP, Bertrand MA. The quality of community colposcopic practice. Obstet Gynecol. 2004;103(1):92-100.

Cite this article as: Parimala A, Sharma N, Srinivasan JK. Prevention of cancer cervix: developing a task force. Int J Reprod Contracept Obstet Gynecol 2016;5:2515-8. 